\section{DoE's management of US nuclear reactors still not satisfactory}

\section{Washington}

DESPITE big strides in improved safety performance, a National Research Council report* concludes that there is still scope for improvement in the management by the Department of Energy (DoE) of its nuclear reactors. The report, released last week, appears just one week after DoE responded to a recommendation of an earlier Research Council report $\dagger$ by proposing two new production reactors to restore US capacity to produce tritium for nuclear weapons.

The two research council reports were originally requested by DoE following the Chernobyl nuclear reactor accident in January 1986. The first report focused on the defence production reactors - three heavy water reactors at the Savannah River Plant in South Carolina, and the graphite-moderated $\mathrm{N}$ Reactor at the Hanford Nuclear Reservation in Washington State. In addition to specific technical safety concerns raised in large measure by the age of the reactors, the 1987 report criticized DoE for a lack of attention to safety, and urged the agency to adopt a clearly articulated safety policy.

DoE has since taken several steps to improve its safety performance. The $\mathrm{N}$ Reactor has been shut down, as has one of the three Savannah River reactors, and the remaining two are operating at decreased power. There has been a 50 per cent increase in the staff of the Office of Environment, Safety and Health, as well as improved administrative procedures and more frequent and broader safety appraisals. The agency also created an independent Advisory Committee for Nuclear Facility Safety, chaired by John F. Ahearne, on which it will "rely heavily".

But Richard Meserve, chairman of the panels that produced the two reports, says the Ahearne committee alone is not sufficient to resolve safety concerns. He says a committee that meets one or two days each month can only begin to address the type of safety issues that operating high powered nuclear reactors present.

The most recent report examines the five Class A (20 MW or greater) DoE test and research reactors. Again ageing is a problem, as is the diversity of designs used in the reactors: the Advanced Test Reactor is a $250 \mathrm{MW}$ light water reactor; the Experimental Breeder Reactor II and the Fast Flux Test Facility are both liquid metal cooled reactors; the High Flux Beam Reactor is a heavy water reactor, and the High Flux Isotope Reactor uses tritium supply problem eases security and

THE United States is in danger of losing a national resource if it fails to take steps to restore the vitality of university research reactors (URRs), according to a report $\S$ released last week by the National Research Council.

There are at present some 40 reactors operating on campuses around the country. The most powerful is a $10 \mathrm{MW}$ reactor at the University of Missouri Columbia campus, but there are two dozen reactors that produce less than $250 \mathrm{~kW}$ of power, right down to a reactor at Manhattan College rated at $0.1 \mathrm{~W}$

Many of the reactors were built $20-30$ years ago, when the now-defunct Atomic Energy Commission was spending heavily on developing nuclear power. But when the commission's responsibilities were divided between the Nuclear Regulatory Commission and the Department of Energy (DoE), the URRs fell through the cracks. Today, DoE contributes about $\$ 2$ million for the operation of the reactors, mainly in the form of fuel.

Operating costs, even of fairly low powered reactors, are typically hundreds light water as a coolant and beryllium as a reflector. The multitude of designs makes numerous safety analyses necessary.

Acknowledging the need to replace the Savannah River reactors, DoE announced last month its plan to build two new production reactors; a heavy water reactor at Savannah River and a modular hightemperature-gas reactor (MHTGR) at the Idaho National Engineering Laboratory. The two-reactor approach to solving the political concerns, but the $\$ 6,800$ million cost of pursuing both technologies may not be fiscally acceptable to Congress.

In January this year, Energy Secretary John S. Herrington requested the DoE Energy Research Advisory Board (ERAB) to produce an analysis of four options being considered by DoE to replace the Savannah River reactors: a new heavy water reactor, a light water reactor, a liquid metal reactor and the MHTGR.

In a report released last month $\ddagger$, ERAB concluded that although all the proposed designs could supply US tritium needs, the heavy water reactor is the most mature technology and would present the fewest technical hurdles. The existence of personnel and facilities at Savannah River, would help keep capital costs down.

But ERAB further concluded that a multiple reactor strategy should assure a steady production capability, reduce uncertainties in the new production reactor schedule and "minimize the technical risks to national security". After heavy water reactors, ERAB considered tritium production technology to be most advanced with MHTGR designs.

Although a heavy water reactor is the most cost-effective way of producing tritium in the short run, proponents of alternative technologies have pointed out that other designs, notably liquid metal and MHTGR, have commercial applications that could help to offset development costs. But ERAB warns that it has been traditional US policy to separate military and civilian nuclear reactor use. "A change in this policy could introduce political risks for the new production reactor project." It could also harm prospects for civilian nuclear power, according to the ERAB report.

DoE must now produce environmental impact statements on its proposals. It will also seek design advice from its newly created Advisory Committee on Nuclear Safety. DoE has $\$ 60 \mathrm{mil}-$ lion in its 1989 budget for work on the new production reactor, but the tough funding decisions - especially as they relate to proceeding with two reactors - will probably wait until after the fall elections.

Joseph Palca

\section{Universities a forgotten resource}

\footnotetext{
*Safety Issues at the DOE Test and Research Reactors. National Academy Press, Washington, DC, 1988
}

$\dagger$ Safety Issues at the Defense Production Reactors. National Academy Press, Washington, DC, 1987.

$\ddagger$ Assessment of Candidate Reactor Technologies for the new Production Reactor. A report of the Energy Research Advisory Board to the United States Department of Energy. Washington, DC, 1988

§University Research Reactors in the United States - Their Role and Value. National Academy Press, Washington, DC, 1988. of thousands of dollars a year, and a large facility such as Missouri has an annual budget of nearly $\$ 4$ million.

Funding comes primarily from indirect charges against research grants, direct support from universities and 'service' functions. These functions can in some cases provide a substantial return. Missouri has been using its neutron flux to irradiate topaz, causing the gemstone to take on a blue colour that increases its commercial value.

But without coordinated federal support, URRs face a difficult future. David Shirley, director of the Lawrence Berkeley Laboratory and chairman of the panel that produced the report, says he believes that an interagency advisory panel would help to coordinate federal support and that a URR would form an excellent focus for one of the new science and technology centres that have been proposed by the National Science Foundation.

The report urges DoE to adopt a network strategy like that centred at the Institut Laue-Langevin in Grenoble, France, where a $57 \mathrm{MW}$ reactor acts as a centre for nuclear research activities, and maintains close ties with university reactor facilities.

Joseph Palca 